\title{
The concept of kotodama as a fragment of Japanese linguocultural code
}

\author{
Anastasia Ignatieva ${ }^{1}$, Natalya Trazanova1* \\ ${ }^{1}$ ISU, Foreign Languages Department, 664000, 8, Lenin St., Irkutsk, Russia
}

\begin{abstract}
The purpose of the article is to study the concept of Kotodama, based on the Kotodama belief, and to analyze the role of this phenomenon in the Japanese linguoculture. In the course of the study, we reveal its origin, evolution and present status. The linguocultural and axiological approaches enable us to represent the main characteristics of Kotodama as an essential part of the Japanese language and culture.
\end{abstract}

\section{Introduction}

From ancient times there has always been a respectful attitude towards the word or the symbol in different cultures and traditions. The Holy Bible says, «In the beginning was the Word», and it was the God, who said it the first. Therefore, primarily the word was supposed to be a sacred entity, endowed with the power of creating things.

It is also believed that the combination of sounds "Om" or "Aum" in Sanskrit radiates Divine Vibrations, produces healing energy and has a variety of sacred meanings, depending on the starting point of interpretation.

It is a well-known fact that the Korean Alphabet hangul is recognized as a cultural heritage of Korea, whose high status is emphasized by the celebration of the Korean Alphabet Day on October, 9 every year.

The Japanese tradition of the gentle and respectful attitude to the word dates back to the ancient times, when the Kotodama belief was born.

According to the Shinto Religion every object of nature was worshipped, the word had a soul which was called Kotodama (there are two ways to write it in Japanese Characters: 言霊 or 言魂). Due to the Shinto beliefs, Kotodama has a magical power to change or create the reality.

\section{Origins of the concept}

The first references to Kotodama were found in the corpus of the Japanese poetry 万葉集 Man'yoshu: "Collection of Ten Thousand Leaves", which goes back to the second half of the $8^{\text {th }}$ century.

As specified in Man'yoshu, Kotodama appears to be one of the exclusively positive and glorious characteristics of Yamato (the old name of Japan), which is connected with Shinto Gods 神 Kami and the Emperor (the descendant of Kami).
Thereby, the origin of the idea, as well as the phenomenon of Kotodama, had been born and evolved on the territory of Japan and particularly in the Japanese language long before the Chinese characters were borrowed.

Originally emperors, priests and poets were supposed to utter the Kotodama-words, because in those times people believed that Kotodama lived in Norito prayers, Emperor's orders and poems Waka (和歌, which means "the Japanese songs" and represents the traditional Japanese poetry). It is also important to note that both prayers and Emperor's orders were put in a poetic form.

Consequently, the main features of spoken words, endowed with Kotodama, are [1]:

1)the words uttered by Shinto Gods Kami;

2)the words passed to the people inhabiting the territory of Yamato;

3)the words used for performing Shinto rituals, in Emperor's acts and speeches, in poetry;

4)the words of prayers, addressed to the Shinto Gods, Buddhas or people;

5)the words have a special magic power, which can influence the recipient, and even can make the Emperor live longer.

Due to the passage of time, the belief in the magic power of the word didn't fade away, but grew stronger, and even turned into the 言霊学 Kotodamagaku "The teaching of a word's soul".

Nowadays the problem of Kotodama draws the attention of both Japanese and foreign researchers. The popularity of studying Kotodama is usually explained by the uniqueness of the Japanese language, territorial limitations and the originality of the Japanese worldview that is closely connected with the Shinto beliefs.

\section{Evolution of the concept of Kotodama and Kotodamagaku}


The term Kotodama was firstly used in the classical literature of the Nara Period (710-784). Famous Japanese ethnologist, folklorist, literary scholar and educator Origuchi Shinobu represented three stages of the change in the meaning of Kotodama in his studies (1927, 1935, 1943) $[2,3,4]$.

The ancient interpretation sends us back to the Divine Powers, which were depicted in the prayer rituals Norito and related to the Shinto beliefs and Shinto Gods Kami. Then there was the first change in the meaning of Kotodama - the Norito prayers were believed to be spiritual, full of souls and spirits, dwelling there. At the final stage syllables, words, language and speech get souls and spirits as well [5].

Afterwards, the developing of the concept of Kotodama was studied by Linguistics that considers Kotodama as a verbal action, where as soon as the word is uttered it is materialized. Probably, there is a connection with the ancient ritual actions ことあげ kotoage «materialization of a word» which included the process of praying to Gods, uttering special words and transferring their souls into the real life.

Since there was a belief that uttered words could make a destiny, the rituals of kotoage were avoided and such manipulations were forbidden [6].

Besides, according to Toyoda's research the ancient Japanese did not distinguish between two meanings of the word こと koto 1) "words" and 2) "things". Consequently, the belief in Kotodama implied that the name was actually equal to the event, which happened when the word was uttered [7].

In the current research the problem of defining the status and role of Kotodama and the influence of Kotodamagaku on the evolution of Japanese and Japanese Linguistic tradition is still relevant. For example, the research of Kazuya Hara is devoted to specifying the role of Kotodama in Japanese Communication (Kazuya Hara, 2001-2002). The various examples of the implicit role of the Kotodama belief in communication show that the influence of this belief really exists and is expressed in different ways, both verbal and non-verbal. On the one hand, Kotodama is understood as a superstition, which causes obstacles to the freedom of speech, on the other hand, "using words carefully, tactfully and considerably" is important and highly appreciated [5].

Russian researcher V.A. Matveenko studies Kotodama in terms of hermeneutics as a way of the Japanese worldview. It is quite an interesting vision of the problem, which reveals a close connection between the concept of Kotodama and the Japanese language. As a result of the research the author concludes that the lack of distinction between words and actions leads to the linguistic transparency of being. Thus, language is considered to be a metaphysical act, which creates the possibility of the persistent formation of being in the world and the human presence in it [6].

So, in scientific circles there are different and sometimes completely controversial theories which demonstrate the concept of Kotodama as a reflection of ancient Shinto beliefs, a superstition or illusion, or a metaphysical entity of the Japanese language.

\section{Model of linguocultural code}

On the basis of the linguocultural approach the term "code" is understood as a system of the worldview categorization which exists in interactions between archetypical and mythological characters and become implemented in the language by axiological concepts, phraseological units, paremiological expressions and precedent texts.

It is also important to define this term from the semiotic point of view, which helps to reveal the following features of the code as a structure [8]:

- the code is a dynamical structure that is related to the other codes and allows one to get the access to the codes of different levels;

- it is a multilevel system;

- a metamodel, providing the key to interpretation of different layers of a code;

- the code is inexhaustible, namely, it is impossible to reach its deepest invariant level, to penetrate into the essence of its phenomenology.

The components of the code might be represented by the axiological concepts of the different levels of the language.

\section{The concept of Kotodama as a fragment of code}

From the perspective of Kotodama studies of both Japanese and foreign researchers the words and expressions, which are supposed to contain Kotodama, are divided into several groups.

\subsection{Imikotoba "substitute words"}

The first group refers to one of the oldest layers of the Japanese language - 忌み言葉 Imikotoba “substitute words". The existence of words, which are prohibited to pronounce aloud, is explained by the ancient belief that animals, fish and birds could speak and understand the human language.

Therefore, instead of the forbidden names of game animals, hunting weapons, fishing gears, as well as the names of hunters and fishermen, the Japanese used imikotoba. For example, けだもの kedamono "a hairy creature" (used instead of the "animal”), うみさち umisachi "sea luck" (instead of "fishing rod”), やまさち yamasachi "forest luck" (instead of hunting weapon), と りのあそび tori no asobi "bird amusement" (instead of fowling) [9].

The groups of substitute words Imikotoba are numerous and not limited to the category of hunting, fishing and names of game animals. The other categories include the following varieties of words: numerals, the names of Gods, priests, emperors, as well as some words, related to travelling, death, blood and impurity.

\subsection{Numerals}


It is worth mentioning that the beliefs related to numerals are relevant at present and exist in everyday life of Japanese.

Thus, for instance, the names of numbers 四 shi "four" and 九 $k u$ "nine" are considered to bring bad luck, because they are homonymic to the words 死 $s h i$ "death" and 苦 $k u$ "suffering". For this reason, a Japanese hardly would pick up a comb left by someone. The name of the comb in Japanese < $L$ kushi is homonymic to both suffering and death, and, consequently, is supposed to bring bad luck [5].

On the opposite, the numbers 三 san "three", 五 go "five" and 七 shichi/nana "seven" are believed to bring good luck in the Japanese linguoculture. The number 三 san "three" has a sacral and magical meaning. A plenty of religious and everyday rituals are usually performed three times. The Japanese put a 五円 goen «five yens» coin into the purse to attract good luck since it sounds the same as ご縁 goen "good luck"/ "life-changing ties", and also is related to the expression 縁がある en ga aru "to be on a lucky streak".

Beyond that, the annual holiday 七五三 shichigosan "seven-five-three" plays a part of a significant landmark event for the children of three, five, seven, which celebrate the coming-of-age ceremony.

The number 八 hachi "eight" also refers to the "lucky" numerals, since the silhouette of it looks like an open fan, which is the symbol of growth, progress and prosperity.

\subsection{Traditional syllabary Iroha}

Not only words and numbers, but also syllables are believed to keep some magic power. Thus, the Japanese phonetic alphabet serves as a striking example demonstrating the possibility to create powerful words.

The first Japanese phonetic alphabet was made at the beginning of the $9^{\text {th }}$ century. The syllables are arranged in the order いろは Iroha and, as a result, form a wellknown poem, which includes every syllable of the alphabet and helps to memorize it:

$\begin{array}{ll}\text { いろはにほへと } & \text { I ro ha ni ho he to } \\ \text { ちりぬるを } & \text { Chi ri nu ru wo } \\ \text { わかよたれそ } & \text { Wa ta yo re so } \\ \text { つねならむ } & \text { Tsu ne na ra mu } \\ \text { うみのおくやま } & \text { U wi no o ku ya ma } \\ \text { けふこえて } & \text { Ke fu ko e te } \\ \text { あさきゆめみし } & \text { A sa ki yu me mi shi } \\ \text { 总ひもせす } & \text { We hi mo se su }\end{array}$

The translation of this poem into English by Professor Ryuichi Abe reads as:

"Although its scent still lingers on the form of a flower has scattered away

For whom will the glory

of this world remain unchanged?

Arriving today at the yonder side

of the deep mountains of evanescent existence

We shall never allow ourselves to drift away intoxicated, in the world of shallow dreams".
The poem allows not only to keep in memory Japanese syllabary, but also to become acquainted with the nature of a human being in the light of the Japanese worldview. This poem represents the ideas of Buddhism, such as the opposition of "doing - undoing", illusiveness and temporality of a human being, evanescence and brevity of life.

Moreover, it is worth drawing attention to the word いろ iro "flower" in the very beginning of the poem, because it has a variety of meanings: "color", "love", "passion". Consequently, there is a possibility to understand and interpret the poem in different ways, which implies the existence of simultaneous parallel interpretations.

The syllabary Iroha is considered to be a culture forming text, and there are certain reasons for that. As we mentioned above, the children were taught to memorize the alphabet with the help of the poem where the things were enumerated in the sequence of $い 、 ろ 、$ は... I, ro, ha... "one, two, three...". This way of the Iroha-order is very popular and is used in the dictionary entries, games, in which Japanese created poems close to rituals (Steiner, 2008). Another game is based on a set of cards, called いろはカルタ Iroha karuta, which consists of cards with pictures and parts of proverbs in the traditional Japanese syllabary order.

As a word いろは Iroha has the meaning "the basics" or "the fundamentals" in Japanese, and the expression いろはのい Iroha no I stands for "the most basic element of all".

Beside the traditional order of the Japanese alphabet, there was also a number of pangrams, known as 手習歌 tenaraiuta "training songs". Probably, the most popular among them is「あめつちのうた」Ame tsuchi no uta "The song of the heaven and the earth":

あめ つち ほし そら
Ametsuchi hoshisora
やま かは みね たに
Yama kahamine tani
くも きり むろ こけ
Kumo kiri muro koke
ひと いぬ うへ する
Hito inu uhe suwe
ゆわ さる おふせよ
Yuwa saru ofuseyo
えのえを なれみて
Eno yewo narewite

A rough translation into English reads:

"Heaven, earth, star, sky,

Mountain, river, ridge, valley,

Cloud, fog, mudhouse, moss,

Person, dog, top, end,

Sulfur, monkey, grow!

Hackberry brunch! Keep getting more familiar!"

This poem includes a list of the components and elements, forming the Universe, supposedly, implies the symbolic meanings, and includes the educational aspect of how the world is organized.

Thus, until the end of the Second World War and the introduction of a new modern syllabary order 五十音 
goju: on "50 syllables", the phonetic alphabet いろは Iroha follow the principles of symbolization, sacralization and syllable order for easy memorizing.

According to the researcher's opinion, until recently the poetic-metaphorical method using rhythmical pangrams has been the dominating way of the syllabary order in Japan. Such way of the arrangement was reasonable, meaningful and conveyed both thoughts, senses and the ideological depth of the worldview [10].

\subsection{Proper names and toponyms}

Further in our research, we consider the category of proper names, which are supposed to contain kotodama and a large fragment of the linguocultural code.

Since ancient times to the present day, the characters in the names were believed to bring good luck or bad luck. These beliefs are traditionally related to the vision of the things and symbols that could provide good luck and protect from the bad one. A talisman, an amulet or as it called in Japanese お守り Omamori has also another name 縁起物 Engimono “A thing, bestowing fortune".

In the process of choosing a name for a newborn, the Japanese usually pay attention to the meaning of characters. Therefore, the dictionaries of proper names play a significant role in the Japanese Lexicography.

As for the toponyms, the great majority of the Japanese geographical names consist of the characters, which are believed to bring good luck, and at the same time, confirm the idea of the magical power of the words and their influence on the life and prosperity of the place. One of the most popular characters used in the names of toponyms is 富 tomi “wealth” [11].

Apparently, abundance and prosperity lie at the root of successful growth and development of any geographical object. There is a number of well-known names, such as: 富士山 Fujisan “the Mount Fuji”, 富山 県 Toyamaken “the Prefecture Toyama” etc.

Besides, the most widespread characters for naming geographical objects are the following:

- 福 fuku "good luck, happiness, well-being" (e.g.: in the names of Prefectures 福岡 Fukuoka, 福島 Fukushima, 福井 Fukui);

- 和 wa "peace, harmony" (in the names of such places as 和歌山 Wakayama, 和光 Wako, 和泉 Idzumi);

- 豊 yutaka "abundant” (in the names of the towns 豊田 Toyota, 豊川 Toyokawa, 豊岡 Toyooka).

Moreover, to strengthen the positive meaning of the toponyms, people repeated or added a "good" character to the name, e.g.: 大 “big”, 新 “new”, 上 “up”, 高 "high”, 喜 “delightful, joyful”.

On the opposite, "bad" characters were avoided in naming geographical objects: e.g.: 下 “down”, 北 “the north", 死 “death”, 禍 “misfortune”, 病 “illness” etc. However, it was possible to change a "bad" name. The name of the city シコツ Shikotsu, which in the Ainu language meant «A big lowland», was homonymic to 死
骨 shikotsu "death and bones". As a result, in 1805 the city was renamed to 千歳 Chitose "A thousand years".

Actually, the idea of renaming is related to the fact that a lot of cranes lived there. It is also a well-known fact that a crane is a symbol of a long life in the Japanese culture, and it can be proved by the proverb: 鶴は千年 、亀は万年 Tsuru wa sennen, kame wa mannen “A crane lives a thousand years, a tortoise lives ten thousand years" [12].

The river in the Chitose City got the same name 千歳 Chitose, but the name of the lake remains the old one, although it is written in different characters 支笏 Shikotsu. In olden days, there were frightening legends about the ghosts, who lived in the lake, and the place itself was notorious for suicides [13].

Nowadays municipal governments still get requests for renaming geographical objects and discuss these questions at the same level as other important issues [11].

\subsection{Prohibited words and set expressions}

Since the earliest times the Japanese traditions have recommended using words carefully and tactfully, especially on special occasions and big events.

At weddings people avoid such words as 離れる hanareru “to break up", 別れる wakareru “to separate”, 終わる owaru “to finish", 切れる kireru "to become torn”, 失う ushinau “to lose”, 避ける sakeru "to avoid”, 捨てる suteru “to throw away”, 去る saru “to leave”, 帰 る kaeru "to return", 返す kaesu "to give back", 断つ tatsu "to cut off”, ほころびる hokorobiru "to come unstitched”, 解ける tokeru “to come untied" etc.

The next group of words and expressions, containing Kotodama, includes set expressions and phrases, which should be used in definite communicative situations. Such kinds of expressions are typical for speaking etiquette, because they are easy to produce and provide a number of set expressions among which the speaker can choose the most suitable one.

Besides, such set phrases are easy to recognize and understand, helping the speaker save face and avoid awkward situations like bluntness in speech. For example, at the end of the working day Japanese people usually use the following expressions: お先に失礼しま す。Osaki ni shitsurei shimasu. "I'm sorry for leaving earlier (than you)" (literal translation), お疲れ様です。 Otsukare sama desu. "Thank you for your today's work and cooperation" (literal translation). The content of these phrases not only recommends and demonstrates colleagues' politeness to each other, but also adds a shade of gratitude and apology to a formal good-bye.

According to the Japanese researchers, proverbs also keep some magic power, and the word "proverb" itself in earlier times was equal to the meaning of the word 呪言 dzyugon "spell" [14].

The proverbs about beliefs and superstitions are striking examples of the concept of Kotodama: 茶碗を 箸で叨くと貧乏神が来る Chawan wo hashi de tataku 
to bimbo: kami ga kuru "If you tap against the bowl with the chopsticks, the God of poverty will come"; 米をこ ぼすと、火事になる Kome wo kobosu to, kaji ni naru "If rice is spilled, the fire will start"; 秋なすは嫁に食わ すな Akinasu wa yome ni kuwasuna "Don't give your bride the eggplants picked in fall" (otherwise she won't have children).

\section{Main characteristics of Japanese as a fragment of linguocultural code}

Careful and sensitive attitude to the word usage as far as minimalism are considered to be a sign of good manners in the Japanese Linguoculture. That is why set expressions and colloquial phrases are usually formulated in a short laconic manner. Ellipsis and incompleteness of sentences are also typical for colloquial everyday speech. The latter means that the recipient reads between the lines, guesses what the speaker has said and reacts properly, namely, according to the expectations of the speaker.

The core features of the Japanese language, which may be considered as the characteristics of the Linguocultural code, are expressed by such key words as 曖昧な aimaina “ambiguous, uncertain, elusive" and 微 妙な bimyouna “delicate, subtle".

Actually, the representatives of the other linguocultures often complain that Japanese phrases are ambiguous and difficult to understand. However, on the other hand, Japanese are never confused communicating with each other. However, the informational gap, which is a significant obstacle for a European, turns into an opportunity to create a comfortable communicative space which is so much appreciated by Japanese. This phenomenon implies the mutual care about each other which lets the listener read between the lines and guess the meaning of an untold message.

As for the second feature, the word 微妙な bimyo: $n a$ has the homonymic variant 美妙な bimyo: na "beautiful, refined", which may serve as one more important characteristic of Japanese. Firstly, because in Japanese there are large groups of words, called 美化語 bikago "beautiful words" (the words, which denote politeness and are used with prefixes of politeness) and 上品な言葉 jo: hinna kotoba "refined words". Secondly, the Japanese language is closely connected with the Japanese culture, which is rich in aesthetic categories and the sense of beauty.

The sublime art of communication is the non-verbal one which also may be considered the significant feature of the Japanese Linguoculture. It may be described by the set expression 以心伝心 Ishindenshin "From heart to heart communication". This phrase implies creating the unified comfortable space for the speakers, co-existing in harmony, on the same wavelength, when it becomes possible to understand and feel each other without any words.

\section{Conclusion}

Summing up, 言霊 Kotodama "a soul of the word" is a unique phenomenon, originated in Japan and still existing in the Japanese culture due to the maintenance and continuity of traditions. In a narrow sense Kotodam is defined as a term related to the ancient Shinto beliefs. In this case, we limit its scope to Norito-prayers, Emperor's orders and traditional poems Waka.

However, according to the current studies, it is necessary to consider the concept of Kotodama wildly, as it lets us observe its influence on the origins and evolution of the Japanese language and culture. Seeing a word as a precious gift, understanding its importance and tangibility, respecting the speaker, avoiding bluntness in communication - all these features of the Japanese language remind us that the word really has a soul.

\section{References}

1. A. N. Meshcheryakov The Origin of the Concept of Word Soul (Kotodama) in ancient Japan. Articles. Interpretative models in Culture. Shagi/Steps. 2015. 1 (1). P.10-18. (in Russian).

2. Origuchi, S. (1927). The Folklore in Shinto. In Origuchi hakushu kinen kodai kenkyujo (Ed.). (1971). The Noted Complete Works of Origuchi Shinobu: 3. Tokyo: Chukoronsha. pp. 145-173.

3. Origuchi, S. (1935). The Belief in Kotodama. In Origuchi hakushu kinen kodai kenkyujo (Ed.). (1971). The Noted Complete Works of Origuchi Shinobu: 1. Tokyo: Chukoronsha. pp. 145-157.

4. Origuchi, S. (1943). The Belief in Kotodama. In Origuchi hakushu kinen kodai kenkyujo (Ed.). (1967). The Noted Complete Works of Origuchi Shinobu: 2. Tokyo: Chukoronsha. (pp. 245-252).

5. Kazuya Hara THE WORD "IS" THE THING: the "Kotodama" Belief in Japanese Communication: PART II // ETC: A Review of General Semantics. Vol. 58. No. 4 (Winter 2001-2002). pp. 408-419. URL: https://www.jstor.org/stable/42578117.

6. V. A. Matveenko On the spirit of words: hermeneutics as a way of Japanese Weltshauung. The Journal of Tomsk State University. Philosophy. Sociology. Politology. 2016. No. 4 (36). P. 184-194. (in Russian).

7. Toyoda, K. (1980). The Japanese Kotodama Belief. Tokyo: Kodansha.

8. У. Эко Отсутствующая структура. IU. Eco La Struttura Assente. Milano: La nave di Teseo editore, 2016. Translation from Italian by V. Reznyk and A. Pogonyailo (in Russian).

9. N.A. Syromyatnikov The ancient variant of Japanese. Moscow.: The Eastern Literature, 2002. P. 57-63. (in Russian).

10. E. Steiner Alphabet as a cultural code: Russia and Japan. The text of lection, February, the 14th, 2008. URL: https://polit.ru/article/2008/02/14/azbooka/. (in Russian).

11. A. R. Sadokova Japanese «happy toponyms» // The relevant Problems of Philology : materials of the III International Conference. (Kazan, may, 2018). Kazan. Young Scientist 2018. p. 18-21. URL: 
https://moluch.ru/conf/phil/archive/301/14121/. （in Russian).

12. 千歳市オフィシャルサイト. URL: https://www.city.chitose.lg.jp/docs/gaiyou.html. (in Japanese).
13. 北海道ファンマガジン. URL: https://hokkaidofan.com/shikotsuko/. (in Japanese). 14. 永山久夫 和食ことわざ辞典. 東京：堂出版, 2014. 2-80 ページ. (in Japanese). 